\title{
Baking characteristics of white bread containing added varieties of rice powder
}

\author{
Yong Myeon Joung* \\ San Cheong Medicinal Herb Confectionery Co., Ltd., Sancheonng 52229, Korea
}

\section{종류별 쌀 분말을 첨가한 식빵의 제빵 특성}

\author{
정용면* \\ (주) 산청약초과자
}

\begin{abstract}
The properties of dough containing added powders of different rice varieties and the bread baking characteristics, based on product preservation evaluation, were compared with those of the control (without added rice). The stability of the dough generally decreased for all the cultivars except for Cambodian rice. Upon addition of $30 \%$ of each rice variety, there was no significant difference in terms of volume between the control and the finished product with added rice. The moisture activity of the rice varieties ranged from 0.944 to 0.946 , and no significant difference was observed in the water activity. However, the product preservation evaluation indicated that the color and puffiness of the breads with added rice varieties were high. According to the overall preservation evaluation, the softness, taste, and moistness of the breads with added rice in the order: glutinous rice, steamed rice, goami rice, rice, and Cambodian rice. Therefore, in the production of breads containing $30 \%$ of rice varieties, the volume and texture of the breads were similar to those of the control, and the elasticity of the products did not decrease even after the storage period of each product. Therefore, we think that it is best to keep the shelf-life of the product.
\end{abstract}

Key words : rice powder, texture, rice white bread, water activity, SEM

\section{서 론}

21세기에 접어들면서 식생활의 패턴이 서구화와 직장인 들에게 쉽게 이용될 수 있는 간편식(햄버거 등)과 한방, 웰빙, 웰리스 등의 건강 지향적이고 안전한 먹거리를 제공 하기 위해 가공 상품개발이 활발하게 진행되고 있다. 쌀은 밀과 함께 세계적인 주식으로 사용하고 있으며 밀은 가루로 제분하여 다양한 제품을 가공하여 섭취한 반면 쌀은 도정하 여 낟알의 형태로 밥을 지어 먹어 왔다. 쌀을 주식으로 했을 때 비만이 억제되고 쌀이 밀을 대체할 수 있는 가장 좋은 곡류이지만 식생활 패턴에 의해 점차 쌀의 섭취가 감소추세

*Corresponding author. E-mail : breadjung2002@daum.net Phone : 82-55-974-2262, Fax : 82-55-974-5202

Received 19 July 2018; Revised 17 September 2018; Accepted 12 November 2018.

Copyright (c) The Korean Society of Food Preservation. All rights reserved.
를 보이고 있다. 쌀은 아시아권에서 대부분 생산되고 주로 소비하고 있으며, 우리나라를 포함한 동아시아의 일본과 중국 일부에서는 자포니카형의 단립종과 중립종으로 끈기 가 있는 밥을 선호하지만 쌀의 소비 촉진을 위해 습식제분, 초미분쇄 등의 쌀 가공기술에 대한 연구가 필요한 실정이다 (1).

쌀을 주식으로 하는 시대에는 가공식품의 섭취가 많지 않았기 때문에 서구 식생활에서 밀을 주식으로 하는 사람들 에게 나타나는 글루텐 알레르기인 셀리악 질병을 최소화하 기 위해 밀가루 가공식품을 적게 섭취하고 21세기 건강과 웰빙시대를 선도할 중요한 미래 산업으로 부각하는 gluten-free 및 저 글루텐 함유 식품을 섭취할 수 있는 식생활 을 통해 건강을 유지 할 수 있다는 연구보고서(2)가 나오면 서 밀을 대신할 곡류로 쌀에 대한 관심이 증가하였다. 쌀은 콜레스테롤 저하 효과, 항산화 효과, 혈압조절, 당뇨조 절, 돌연변이 억제 및 암 예방 효과 등 몸에 좋은 영양성분과 유효성분이 있는 것으로 보고되고 있다(3). 한편 대부분의 
국가에서도 gluten-free 식품으로 쌀을 소재로 하여 제품 개발과 제분 방법을 다양하게 연구하고 있지만 먼저 쌀가루 제분 시 사용되는 제분기의 종류 및 제분 방법은 쌀가루의 기능성에 크게 영향을 주는 것으로 알려져 있다(4). 제분 방법에서 습식제분에 비해 건식제분에 의한 쌀 분말은 전분 손상도(5)가 높아 떡류나 과자류 등의 쌀 가공식품에 바람 직하지 못한 영향을 주는 것으로 보고된바 있다(6). 한편 전분의 호화과정에서 물성변화 및 단백질과의 상호작용, 아밀로오스와 아밀로펙틴의 역할, 전분입자를 포함하는 쌀 가루 입자 등에 관해 지속적인 연구가 필요하다고 생각되며 앞으로 건강지향성 제품에 대한 관심이 높아지면서 쌀을 첨가한 베이커리에 관련 많은 연구가 수행되어 왔는데, $\operatorname{Kim}$ 등(7)은 가온 수침처리가 습식제분 쌀가루의 특성에 미치는 영향, Ju 등(8)은 쌀가루 혼합분으로 제조한 스펀지 케이크의 품질 특성에 관해 연구한 사례가 있다.

밀가루로 만드는 빵은 밀에 함유되어 있는 단백질인 글 루텐을 형성하여 반죽에 망상구조를 이루게 되고 굽는 과정 에서 이 글루텐이 증기압에 의해 팽화되어 빵의 부피를 형성하지만 쌀가루에는 $6.5 \%$ 정도의 단백질인 glutelin을 이루고 있으므로 밀 단백질의 팽화에 의한 조직감을 형성하 지 못하기 때문에 그에 대한 보완을 위해 gluten, guar gum, cassava starch, locust bean gum 등의 글루텐 대체 재료들의 첨가는 밀가루 빵과 유사한 조직감을 갖는 gluten-free bread 의 제조를 가능하게 한다고 보고하고 있다(9).

본 연구는 소맥분에 쌀 분말을 종류별로 첨가한 식빵의 $\mathrm{pH}$, 수분활성도(Aw), 색도, 식빵의 부피, 주사전자현미경 (SEM)관찰 및 저장기간에 따른 식빵의 물성변화 측정과 관능검사를 실시하여 쌀 식빵의 최적 조건과 저장성을 검토 하였다.

\section{재료 및 방법}

본 실험에 사용된 쌀은 아밀로스함량이 $16-18 \%$, 단백질 함량은 7-8\%, 수분함량은 $15.5-16.5 \%$ 기준으로 하였다. 쌀 종류별 품종은 한국산으로 경남 고성에서 2017년에 재배된 고아미(밀양 168호), 멥쌀(밀양 122호), 찹쌀(익산 438호)로 가족사랑 쌀 작목반에서 도정한 것을 구입하였다. 멥쌀 및 찐 찹쌀 제조는 $25^{\circ} \mathrm{C}$ 물에 48 시간 침지시킨 후 경남과학기 술대학교 제빵실습에서 스팀을 이용하여 30 분간 찜을 하여 72 시간 건조시켜 도정하였다. 캄보디아(자포니카형) 쌀은 2017년 수확한 쌀을 구매하였다. 고아미, 멥쌀, 찐 멥쌀, 찐 찹쌀, 캄보디아 쌀 5 종류를 균일한 건조 조건을 위해 실온에서 10 일 건조시킨 후 만수제약(주)에서 각 종류별 쌀 분말을 $200 \mathrm{mesh}$ 로 분쇄하여 냉장고에 보관하며 사용하 였다. 대조구에 사용한 밀가루는 대한제분의 강력분을 구 입하여 사용하였으며, 부재료 탈지분유(Seoul milk, Seoul
Korea), 소금(Han ju, Incheon, Korea) 버터(Lotte samgang, Yangsan, Korea), 생이스트 및 제빵개(SIB, Asan, Korea) 등을 사용하였다.

\section{식빵의 제조방법}

식빵의 배합률은 Table 1 과 같이 AACC(10)방법 $10-10 \mathrm{~b}$ 의 방법을 수정하여 직접법 실시하였다. 쌀 소비 촉진을 위해 배합표 기준 $20 \%$ 의 예비 실험결과는 기존 밀가루 $100 \%$ 첨가한 제품과 유사한 조직과 식감을 갖춘 제품이 생산되었으며, 쌀 종류별 $40 \%$ 첨가하여 실험한 결과에서는 떡과 같은 식감과 조직이 나타났으므로, 본 실험에서는 쌀 종류별 $30 \%$ 를 소맥분에 첨가하는 방법으로 결정하였다. 이때 식빵 제조는 Fig. 1과 같은 방법인 직접법(straight dough method)으로 하였다. 식빵의 제조공정은 배합기 Maximat N-40S(G. L. Eberhardt GmbH, Gräfelfing, Germany)를 사용하였고, 최종 반죽온도는 $27^{\circ} \mathrm{C}$ 로 하였다. 발효 조건은 상대습도 $75 \%$, 온도 $28^{\circ} \mathrm{C}$, 시간은 120 분간 소요되었다.

발효가 끝난 반죽은 손으로 펀칭하여 가스를 뺀 후 200 $\mathrm{g}$ 으로 분할하여 둥글리기를 하고 실온에서 20 분간 중간 발효한 후 성형하여 반죽 팬에 넣고 Fresh proofer(Dae yung bakery Co., Ltd., Seoul, Korea) 2차 발효를 40분 후 Electric deck oven(Daeyung bakery Co.)에서 구워 낸 다음 상온에서 1 시간 냉각한 후 시료로 사용하였다.

Table 1. Formula of bread dough

\begin{tabular}{ccc} 
& & (unit: \% of flour basis) \\
\hline Ingredients & Control (\%) & Test (\%) \\
\hline Bread flour & 100 & 70 \\
Water & 65 & 65 \\
Rice powder & 0 & 30 \\
Yeast & 2 & 2 \\
Sucrose & 8 & 8 \\
Salt & 2 & 2 \\
Non-fat dry milk & 2 & 2 \\
Butter & 3 & 3 \\
Improvers of bread & 2 & 2 \\
\hline
\end{tabular}

\section{식빵의 $\mathrm{pH}$ 측정}

식빵의 $\mathrm{pH}$ 측정은 $\mathrm{pH}$ meter(TM 300 Series, Beckman Coulter Inc, Washingrton DC, USA)를 사용하였다(11). 구워 낸 식빵을 3시간 정도 냉각시킨 다음 크럼(crumb) $10 \mathrm{~g}$ 을 취해 $250 \mathrm{~mL}$ 비커에 넣고 $90 \mathrm{~mL}$ 증류수를 가해 균일하 게 혼합한 후 측정한 값을 3 회 반복 측정하여 평균값을 내었다. 


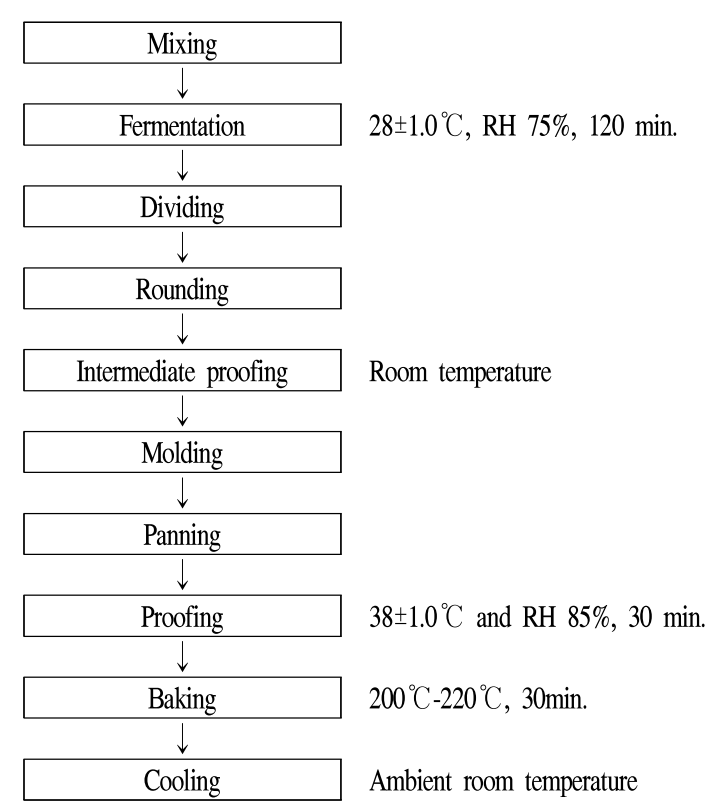

Fig. 1. Flow chart for bread making.

\section{식빵의 부피 측정}

Loaf volume은 식빵을 구운 후 실온에서 2시간 방치 한 식빵의 한 덩어리를 일정한 위치의 가장 높은 부분에서 세로로 절단하여 중심점에서 바닥에서 높이를 3회 반복 측정하여 평균값을 사용하였다.

\section{식빵의 색도 측정}

색도 측정은 색차계 Color reader(CR-300 Chroma Meter, Minolta Camera Co., Tokyo, Japan)를 사용하였다(12), 식빵 크럼 부위를 가로, 세로, 높이 각 $20 \times 20 \times 10 \mathrm{~mm}$ 로 잘라 시료를 만들었으며, 이때 표준 색판의 $\mathrm{L}, \mathrm{a}$ 및 $\mathrm{b}$ 값은 각각 $95.91,0.00,2.27$ 이었다. 측정값은 Hunter의 명도(L, lightness), 적색도(a, redness), 황색도(b, yellowness)를 3회 반복 측정하여 평균값을 사용하였다.

\section{식빵의 수분활성도 $(\mathrm{Aw})$ 측정}

수분활성도(Aw)의 측정은 구워낸 식빵 크럼을 1 시간 후 에 Aw meter(BT-RS1, Rotronicag, Bassersdorf, Swiss)를 사 용하였다(13). 시료 $3 \mathrm{~g}$ 을 밀폐 플라스틱 용기에 넣고 $20^{\circ} \mathrm{C}$ 에 보관하면서 수분활성도 값이 더 이상 변화가 없을 때의 값을 3회 반복 측정하여 평균값을 사용하였다.

\section{조직감 측정}

저장 기간에 따른 식빵의 조직감 측정은 Rheometer(CR100D, Sun Scientic Co., Ltd., Tokyo, Japan)에 직경이 20 $\mathrm{mm}$ 인 adaptor를 사용하여 adaptor 진입 거리를 $10 \mathrm{~mm}$ 감지 센스의 최대값을 $2 \mathrm{~kg}$ 으로 고정하였다. 시료는 식빵의 크럼 부위를 가로, 세로, 높이 각각 $40 \times 40 \times 30 \mathrm{~mm}$ 로 잘라 만들었 다. 밀폐 플라스틱 용기에 넣고 상온 $\left(20^{\circ} \mathrm{C}\right)$ 에서 $1,2,3,4$ 일
간 보관하면서 경도(hardness), 탄력성(springiness, 검성 (gumminess) 값을 각 시료를 3회 반복 측정하여 평균(을 사용하였다.

$$
\text { Hardness }\left(\text { dyne } / \mathrm{cm}^{2}\right)=\frac{\operatorname{strength}\left(\text { dyne } / \mathrm{cm}^{2}\right) \times \text { sample height }(\mathrm{mm})}{\text { distance }(\mathrm{mm})}
$$

\section{주사전자현미경(SEM) 관찰}

주사전자현미경(scanning electron microscope) 관찰은 시료 $10 \mathrm{~g}$ 을 Vacuum tray freeze dryer(TD 6070K, Ilsin Engineering Co., Seoul, Korea)에서 진공동결 건조한 식빵 시료(수분함량: 2\%)를 ion spotter(E-1010, Hitachi, Tokyo, Japan)에서 60초간 백금 도금한 후 주사전자현미경 (S-3500N, Scanning electron microscope, Hitach, Tokyo, Japan)으로 가속 전압 $10 \mathrm{KV}$ 조건에서 $500,1,000$ 및 1,500 배율로 확대하여 각각의 시료를 비교 관찰하였다(14).

\section{통계 처리}

통계 분석은 SAS/STAT 9.1(Statistical Analysis System, Cary, NC, USA) 통계 프로그램을 사용하여 분산 분석 (one-way ANOVA)을 실시하였고(15), 각 시료 간의 유의성 검증은 Duncan's multiple range test를 사용하였다 $(\mathrm{p}<0.05)$.

\section{결과 및 고찰}

\section{식빵의 $\mathrm{pH}$}

소맥분에 쌀 종류별 분말을 각각 $30 \%$ 첨가하여 식빵을 제조한 후 실온에서 완전하게 식힌 다음 제품의 $\mathrm{pH}$ 를 측정 한 결과 Table 2 와 같다.

대조구의 $\mathrm{pH}$ 는 $6.47 \pm 0.23$ 으로 나타났으며, 멥쌀, 고아미, 찐 멥쌀, 찐 찹쌀 및 캄보디아 쌀 분말은 각각 $6.533 \pm 0.12$, $6.58 \pm 0.24,6.73 \pm 0.13,6.77 \pm 0.22$ 및 $6.52 \pm 0.23$ 로 나타났다. Nakae(16)는 반죽이 발효됨에 따라 발효성 당류에 의해 생성되는 이산화탄소와 발효 시 생성되는 유기산류에 의하 여 $\mathrm{pH}$ 가 떨어지게 된다고 하였다. 본 실험에서는 소맥분에 멥쌀, 고아미, 찐 멥쌀, 찐 찹쌀 및 캄보디아 쌀 분말을 첨가 한 혼합분에 첨가한 혼합약초의 $\mathrm{pH}$ 가 6.5-7.2 정도이므로 이를 첨가한 식빵의 $\mathrm{pH}$ 가 대조구보다 다소 높은 것은 쌀 분말에 함유되어 있는 당류가 대조구보다 낮은 것으로 판단 되었기 때문이다.

Table 2. $\mathrm{pH}$ of white pan bread added with $30 \%$ of different kinds of rice powder

\begin{tabular}{ccccccc}
\hline Sample & Control $^{1)}$ & Rice & $\begin{array}{c}\text { Goami } \\
\text { ricer }\end{array}$ & $\begin{array}{c}\text { Steamed } \\
\text { rice }\end{array}$ & $\begin{array}{c}\text { Steamed } \\
\text { glutinous } \\
\text { rice }\end{array}$ & $\begin{array}{c}\text { Cambodia } \\
\text { rice }\end{array}$ \\
\hline $\mathrm{pH}$ & $6.47 \pm 0.23$ & $6.53 \pm 0.12$ & $6.58 \pm 0.24$ & $6.73 \pm 0.13$ & $6.77 \pm 0.22$ & $6.52 \pm 0.23$ \\
\hline${ }^{1)}$ control, wheat flour & $100 \%$. & & & &
\end{tabular}




\section{식빵의 부피}

소맥분에 멥쌀, 고아미, 찐 멥쌀, 찐 찹쌀 및 캄보디아 쌀 분말 각각 $30 \%$ 첨가하여 제조한 식빵의 부피를 측정한 결과는 Fig. 2 와 같다. 발효시간 30 분 경과함에 따라 1.5 배의 부피가 증가하였고 60 분이 경과했을 때는 반죽의 1.6 배의 부피가 증가하였으며, 식빵을 구웠을 때 각각의 종류별 쌀 분말 $30 \%$ 첨가구에서는 대조구와 부피를 비교했을 때 쌀 분말을 첨가한 식빵 완제품에서는 영향이 없는 것으로 나타 났다.

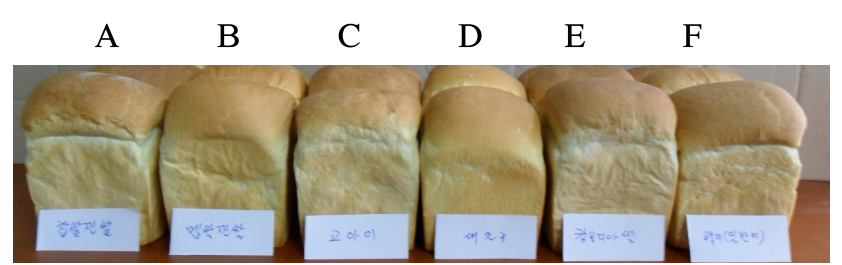

Fig. 2. Volume of white pan bread added with $30 \%$ of different kinds of rice powder.

A, steamed glutinous rice; B, steamed rice; C, goami rice; D, control (wheat flour); $\mathrm{E}$, cambodian rice; $\mathrm{F}$, rice.

\section{식빵의 색도}

소맥분에 멥쌀, 고아미, 찐 멥쌀, 찐 찹쌀 및 캄보디아 쌀 분말을 각각 $30 \%$ 첨가하여 제조한 식빵의 크럼을 실온 에서 완전히 냉각한 다음 저장기간에 따라 색도 변화를 조사한 결과는 Table 3 과 같다.

대조구 크럼의 $\mathrm{L}, \mathrm{a}$, 및 $\mathrm{b}$ 를 조사한 결과 각 $78.24,-1.26$, 13.96 이었다. 일반 분쇄한 쌀 분말의 종류별 $30 \%$ 첨가한 첨가구의 $\mathrm{L}, \mathrm{a}$, 및 $\mathrm{b}$ 의 1 일 차의 값은 멥쌀 $74.90,-1.37$, 15.29 , 고아미 $78.40,-1.50,13.0$, 찐 멥쌀 $75.76,-2.21,16.44$,
찐 찹쌀 $78.03,-2.03,15.23$, 캄보디아 쌀 분말은 $78.53,-1.27$, 13.18 이었다. $\mathrm{L}$ 값의 경우 쌀 종류별에서는 멥쌀과 고아미 가 약간 낮게 나타났으며, $\mathrm{a}, \mathrm{b}$ 값은 저장 1 일째 일정한 경향을 보이지 않았다. 일반적으로 L 값은 쌀 종류별 분말 을 첨가할 경우 빛을 난반사하여 더 높게 나타났다. Park 등(17)은 쌀가루의 입도에 따른 쌀 식빵의 품질 특성연구에 서 쌀 분말을 첨가할수록 제품 내부의 값이 높아졌다는 보고는 이는 본 연구의 분석결과와 일치하였다.

\section{식빵의 수분활성도 $(A w)$}

소맥분에 멥쌀, 고아미, 찐 멥쌀, 찐 찹쌀 및 캄보디아 쌀 분말을 각각 $30 \%$ 첨가하여 제조한 식빵을 상온에서 완전히 냉각시킨 후 밀폐 프라스틱 용기에 넣어 $20^{\circ} \mathrm{C}$ 온장 고에서 보관하면서 저장기간에 따른 수분활성도를 측정한 결과는 Fig. 3 과 같다.

$1,2,3$ 및 4 일 간격으로 조사한 결과 쌀 분말 종류별 $30 \%$ 첨가한 식빵 크럼의 경우 첨가구의 1-4일까지 수분활성도 는 대조구는 0.971 에서 0.955 으로 감소하였고, 4 일 차의 수분활성도는 멥쌀, 고아미, 찐 멥쌀, 찐 찹쌀, 캄보디아 쌀 분말에서는 유의적인 차이가 나타나지 않았다. Kim과 Shin(18)은 입자크기가 다른 쌀가루에서 $200 \mathrm{mesh}$ 쌀가루 의 수분결합력이 가장 높게 측정되었다고 보고하였으며, 식빵을 제조한 쌀 종류별의 입도 차와 수분결합력 차이로 인하여 수분활성도는 대조구와 비슷한 경향을 보였다. Czuchajowska 등(19)은 식빵 반죽의 수분흡수율과 굽기 시 간에 따라 수분활성도를 측정하여 비교한 결과 수분활성도 는 수분흡수율이 감소할수록 굽기 시간이 증가할수록 낮아 지는 경향을 나타내었다.

Table 3. Color of white pan bread added with $30 \%$ of different kinds of rice powder during storage

\begin{tabular}{|c|c|c|c|c|c|c|c|c|}
\hline \multicolumn{2}{|c|}{ Sample group } & Control & Rice & Goami rice & Steamed rice & $\begin{array}{l}\text { Steamed glutinous } \\
\text { rice }\end{array}$ & Cambodian rice & F-value \\
\hline \multirow{3}{*}{$\begin{array}{l}1^{\text {st }} \text { day } \\
\text { storage }\end{array}$} & $\mathrm{L}$ & $78.24 \pm 0.0^{1)(2)}$ & $74.91 \pm 0.0^{\mathrm{f}}$ & $78.39 \pm 0.1^{\mathrm{b}}$ & $75.76 \pm 0.0^{\mathrm{e}}$ & $78.03 \pm 0.0^{\mathrm{d}}$ & $78.53 \pm 0.0^{\mathrm{a}}$ & $19,811.1^{* * *}$ \\
\hline & $\mathrm{a}$ & $-1.26 \pm 0.0^{\mathrm{a}}$ & $-1.37 \pm 0.0^{b}$ & $-1.49 \pm 0.1^{\mathrm{c}}$ & $-2.21 \pm 0.0^{\mathrm{e}}$ & $-2.03 \pm 0.0^{\mathrm{d}}$ & $-1.26 \pm 0.0^{\mathrm{a}}$ & $977.04^{* * *}$ \\
\hline & $\mathrm{b}$ & $13.95 \pm 0.1^{\mathrm{c}}$ & $15.29 \pm 0.0^{\mathrm{b}}$ & $13.00 \pm 0.0^{e}$ & $16.44 \pm 0.0^{\mathrm{a}}$ & $15.23 \pm 0.0^{b}$ & $13.18 \pm 0.0^{\mathrm{d}}$ & $4,011.56^{* *}$ \\
\hline \multirow{3}{*}{$\begin{array}{l}2^{\text {nd }} \text { day } \\
\text { storade }\end{array}$} & $\mathrm{L}$ & $74.39 \pm 0.0^{\mathrm{e}}$ & $77.77 \pm 0.1^{\mathrm{c}}$ & $77.28 \pm 0.1^{\mathrm{d}}$ & $78.82 \pm 0.0^{\mathrm{a}}$ & $78.00 \pm 0.1^{b}$ & $77.95 \pm 0.0^{\mathrm{b}}$ & $1,421.02^{* * *}$ \\
\hline & $\mathrm{a}$ & $-2.36 \pm 0.3^{c}$ & $-2.08 \pm 0.0^{b c}$ & $-2.09 \pm 0.6^{\mathrm{bc}}$ & $-1.57 \pm 0.0^{\mathrm{a}}$ & $-1.54 \pm 0.0^{\mathrm{a}}$ & $-1.65 \pm 0.0^{\mathrm{ab}}$ & 4.95 \\
\hline & $\mathrm{b}$ & $14.68 \pm 0.0^{\mathrm{a}}$ & $12.44 \pm 0.0^{\mathrm{d}}$ & $14.31 \pm 0.2^{\mathrm{b}}$ & $14.38 \pm 0.0^{b}$ & $14.11 \pm 0.1^{\mathrm{c}}$ & $11.30 \pm 0.0^{\mathrm{e}}$ & $572.34^{* * *}$ \\
\hline \multirow{3}{*}{$\begin{array}{l}3^{\text {rd }} \text { day } \\
\text { storage }\end{array}$} & $\mathrm{L}$ & $76.62 \pm 0.0^{e}$ & $79.37 \pm 0.2^{\mathrm{a}}$ & $77.82 \pm 0.0^{c}$ & $76.95 \pm 0.1^{\mathrm{d}}$ & $78.23 \pm 0.2^{b}$ & $77.77 \pm 0.2^{\mathrm{c}}$ & $112.87^{* \star *}$ \\
\hline & $\mathrm{a}$ & $-2.63 \pm 0.0^{\mathrm{e}}$ & $-1.84 \pm 0.0^{\mathrm{d}}$ & $-1.49 \pm 0.0^{b}$ & $-1.74 \pm 0.0^{c}$ & $-1.46 \pm 0.0^{b}$ & $-0.46 \pm 0.0^{\mathrm{a}}$ & $2,010.66^{* * *}$ \\
\hline & $\mathrm{b}$ & $16.09 \pm 0.0^{\mathrm{a}}$ & $14.26 \pm 0.1^{\mathrm{d}}$ & $14.17 \pm 0.0^{\mathrm{d}}$ & $13.73 \pm 0.2^{\mathrm{e}}$ & $14.94 \pm 0.0^{\mathrm{b}}$ & $14.67 \pm 0.0^{c}$ & $231.73^{* * *}$ \\
\hline \multirow{3}{*}{$\begin{array}{l}4^{\text {th }} \text { day } \\
\text { storage }\end{array}$} & $\mathrm{L}$ & $75.56 \pm 0.4^{\mathrm{e}}$ & $75.83 \pm 0.0^{\circ}$ & $78.41 \pm 0.0^{c}$ & $79.53 \pm 0.2^{b}$ & $77.38 \pm 0.0^{d}$ & $80.12 \pm 0.0^{\mathrm{a}}$ & $317.03^{* * *}$ \\
\hline & $\mathrm{a}$ & $-2.34 \pm 0.1^{\mathrm{d}}$ & $-2.30 \pm 0.0^{\mathrm{d}}$ & $-0.86 \pm 0.1^{\mathrm{c}}$ & $-0.24 \pm 0.0^{b}$ & $-0.31 \pm 0.0^{b}$ & $0.22 \pm 0.1^{\mathrm{a}}$ & $594.77^{* * *}$ \\
\hline & $\mathrm{b}$ & $14.99 \pm 0.2^{\mathrm{d}}$ & $13.39 \pm 0.0^{\mathrm{e}}$ & $15.25 \pm 0.1^{\mathrm{c}}$ & $15.98 \pm 0.1^{\mathrm{b}}$ & $18.16 \pm 0.0^{\mathrm{a}}$ & $14.89 \pm 0.1^{\mathrm{d}}$ & $677.80^{* * *}$ \\
\hline
\end{tabular}

\footnotetext{
${ }^{1)}$ Values are Mean \pm SD $(n=5)$.

${ }^{2) a-f}$ Means with the different letter in the same row are significantly different by Duncan's multiple range test $(\mathrm{p}<0.05)$.
} 




Fig. 3. Water activity of white pan bread added with $30 \%$ of different kinds of rice powder during storage.

A, control (wheat flour); B, rice; C, goami rice; D, steamed rice; E, steamed glutinous rice; $\mathrm{F}$, cambodian rice.

한편 본 실험에서는 대조구를 제외하고 쌀 분말 종류별 수분활성도가 0.944-0.946으로 저장 4일째까지는 쌀 분말 종류와 관계없이 수분활성도는 유의적 차이가 나타나지 않음을 알 수 있었다. 그러나 모든 쌀 분말의 종류별 첨가구 에서 4일째부터는 수분활성도가 감소하는 경향을 보였으 며, 이 결과로 예측하여 볼 때 4 일까지는 식빵의 부드러움을 유지할 수 있으리라 판단된다.

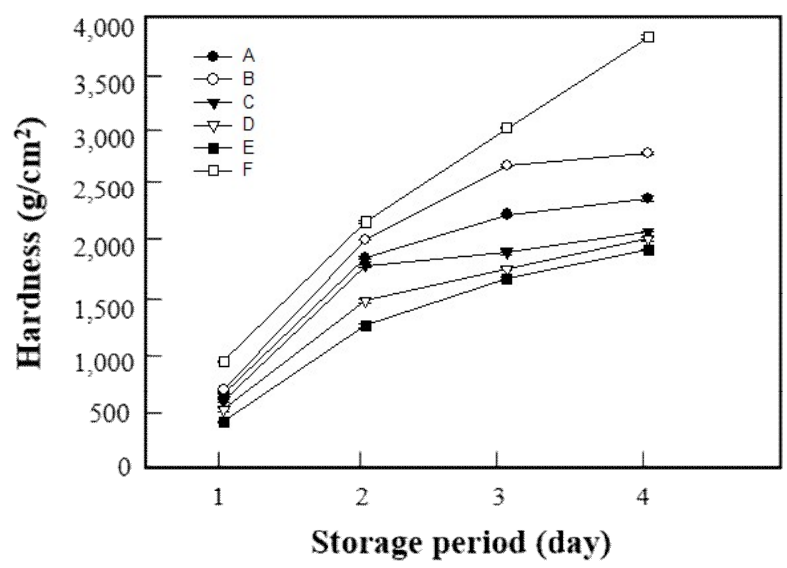

Fig. 4. Hardness of white pan bread added with $30 \%$ of different rice flour during storage

A, control (wheat flour); B, rice; C, goami rice; D, steamed rice; E, steamed glutinous rice; $\mathrm{F}$, cambodian rice.

\section{식빵의 조직감}

경도는 $1,2,3$ 및 4 일 간격으로 측정한 결과는 Fig. 4 와 같다. 일반 분쇄한 쌀 종류별 $30 \%$ 첨가한 1 일 차의 크럼은 $735 \pm 8,643 \pm 7.8,566 \pm 17,461 \pm 4.2,984 \pm 7.3 \mathrm{~g} / \mathrm{cm}^{2}$ 로 유의적 차이를 보였고, 찐 찹쌀, 찐 멥쌀, 고아미 및 멥쌀 분말은 대조구와 비교할 때 저장기간이 4일이 지난 경우에도 대조 구와 유의적인 차이를 보였다. 탄력성(springiness) 측정결
과는 Fig. 5 와 같다. $1,2,3$ 및 4 일째의 대조구는 $87 \pm 1.1$, $89 \pm 1.0,90 \pm 0.0,91 \pm 0.2 \%$ 이었다. 일반 분쇄한 쌀 분말 종류 별 $30 \%$ 를 첨가한 식빵의 크럼이 저장기간에 따라 멥쌀은 $86 \pm 0.3,89 \pm 1.8,90 \pm 0.8,91 \pm 1.6,83.0 \pm 1.1 \%$, 고아미 $87 \pm 0.2$, $88 \pm 0.6,90 \pm 0.8,91 \pm 1.1 \%$, 찐 멥쌀 $85 \pm 0.4,88 \pm 1.5,89 \pm 0.2$, $91 \pm 1.0 \%$, 찐 찹쌀 $87 \pm 0.2,88 \pm 1.4,90 \pm 0.5,91 \pm 2.0 \%$, 캄보디 아 쌀 분말은 $87 \pm 4.2,89 \pm 0.1,91 \pm 0.2,92 \pm 0.9 \%$ 로 나타났다. 검성(gumminess) 값의 결과는 Fig. 6 과 같으며 저장기간이 길어짐에 따라 증가하였지만 찐 찹쌀, 찐 멥쌀, 고아미는 대조구보다 현저하게 낮은 값을 보였다.

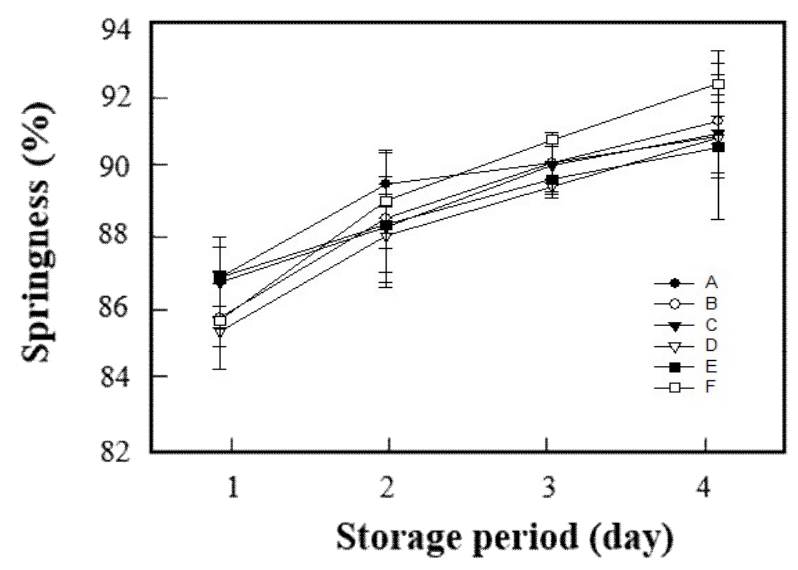

Fig. 5. Springiness of white pan bread added with $30 \%$ of different rice flour.

A, control (wheat flour); B, rice; C, goami rice; D, steamed rice; E, steamed glutinous rice; $\mathrm{F}$, cambodian rice.

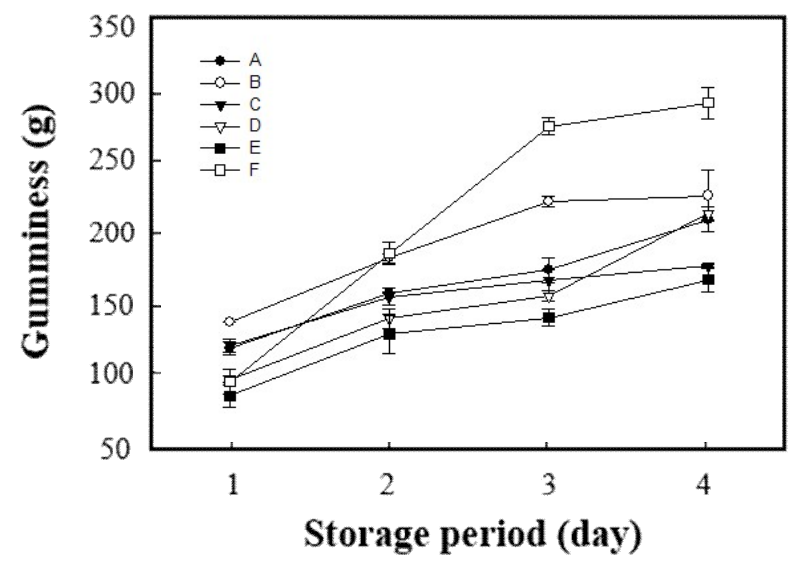

Fig. 6. Gumminess of white pan bread added with $30 \%$ of different rice flour.

A, control (wheat flour); B, rice; C, goami rice; D, steamed rice; E, steamed glutinous rice; $\mathrm{F}$, cambodian rice.

본 실험에서 식빵을 제조할 때 쌀 종류별 분말을 첨가함 에 따라 각각의 저장 기간에서 식빵의 경도는 대조구에 비교할 경우 캄보디아 쌀 분말을 제외하고는 감소하였고, gumminess 값은 약간 증가하였지만 식빵의 가장 좋은 맛을 
유지할 수 있는 상미기한은 3 일로 하는 것이 바람직하다고 판단된다.

\section{식빵의 주사 전자현미경 (SEM) 관찰}

일반 분쇄한 쌀 분말을 소맥분에 각각 종류별 $30 \%$ 첨가 한 식빵을 완전히 식힌 후 진공동결건조한 다음 주사 전자 현미경으로 $500,1,000$ 및 1,500 배율로 관찰한 결과는 Fig. 7과 같다.

(1)

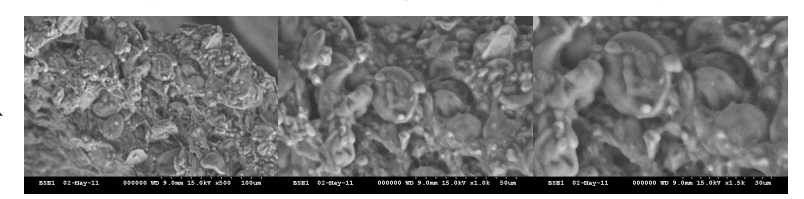

B

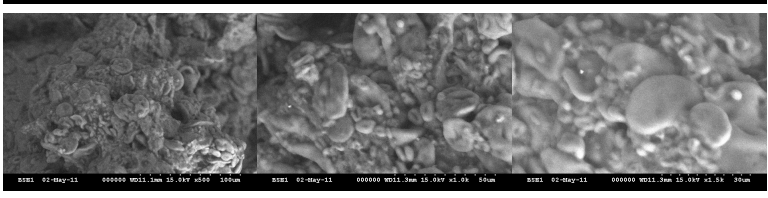

C

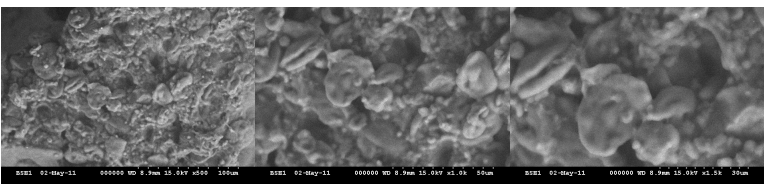

D

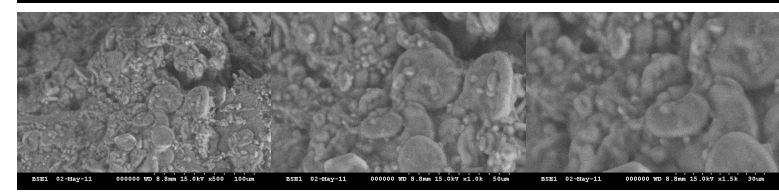

E

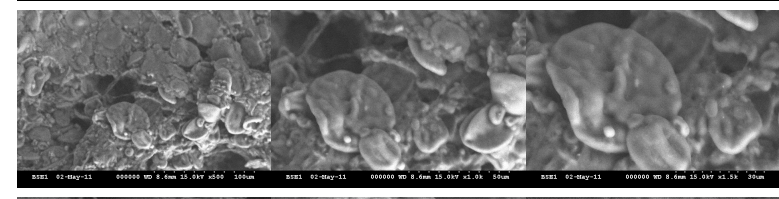

F



Fig. 7. Micrograph of white pan bread added with $30 \%$ of different kinds of rice powder.

(1) $\times 500$, (2) $\times 1,000$, (3) $\times 1,500$.

A, control (wheat flour); B, rice; C, goami rice; D, steamed rice; E, steamed glutinous rice; $\mathrm{F}$, cambodian rice.

즉 대조구의 내부조직은 구형과 타원형의 크고 작은 매 끄럽고 팽윤된 전분입자들이 변성된 단백질과 망상구조를 하고 있는 모양이 관찰되었다. 한편 일반 분쇄한 쌀 분말 종류별 $30 \%$ 를 첨가한 멥쌀 분말의 경우 크럼의 조직내부는 팽윤된 전분과 변성된 단백질이 상호 작용하여 망상구조를 하고 있는 모양이 대조구보다 매끄럽게 관찰되었고, 고아 미는 500 배율에서는 대조구와 유사하며 1,000 배율에서는 구형과 타원형의 크고 작은 전분입자 표면의 매끄러움과 가운데 갈라진 부분과 전분이 손상되어 입자가 구형과 타원
형보다는 길쭉한 형태로 나타났다. 찐 찹쌀은 찐 멥쌀 분말 보다 1,000 배율에서 더 많이 팽윤된 구형과 타원형의 전분 입자가 증가하고 윤곽이 뚜렷하였다. 캄보디아 쌀 분말은 500 배율에서 찐 찹쌀 분말과 유사하였으며, 1,000 배율에서 는 다른 쌀 분말 종류보다 엉김이 많이 형성되고 구형과 타원형의 전분입자가 파괴된 것으로 관찰되었다.

\section{요 약}

본 연구는 소맥분에 $200 \mathrm{mesh}$ 로 분쇄한 쌀 종류별 분말을 첨가한 식빵의 제빵 특성을 연구하기 위해 식빵의 부피, $\mathrm{pH}$, 색도, 수분활성도, 식빵의 조직감, 주사전자현미경 (SEM)을 측정하였다. 식빵의 부피는 종류별 쌀 분말을 각 각 $30 \%$ 첨가한 제품을 구웠을 때 대조구와 비교한 결과 큰 차이는 나타나지 않았다. 수분활성도는 쌀 분말 종류별 로 0.944-0.946 범위였고, 저장 4일째에 쌀 종류와 30\% 첨가 량에 관계없이 수분활성도는 유의적 차이가 나타나지 않았 다. 기계적 조직감 측정에서 경도, 탄력성, 검성 등의 값에서 경도 값에서만 대조구와 유의적인 차이를 보였으며 검성 (gumminess)은 저장기간이 길어짐에 따라 증가하였지만 찐 찹쌀, 찐 멥쌀, 고아미는 대조구보다 현저하게 낮은 값을 보였다. 소맥분에 쌀 종류별 $30 \%$ 첨가구에서는 전분의 결 정화 억제로 전분입자의 매끄러운 정도가 증가되어 저장기 간 1-4일까지 식빵의 경도에서는 대조구와 비교할 경우 캄보디아 쌀 분말을 제외하고는 감소하였다. 탄력성은 저 장기간이 경과함에 따라 감소한다는 것은 식빵의 품질이 떨어진다는 의미이지만 본 실험에서는 쌀 분말 종류별 $30 \%$ 첨가한 식빵 제조에서는 대조구와 유사한 부피와 식감을 보였다. 각 쌀 분말을 첨가한 식빵은 저장기간이 경과하여 도 식빵의 탄력성이 감소하지 않았다. SEM 측정 결과 대조 구는 구형과 타원형의 크고 작은 매그럽고 팽윤된 전분입자 들이 변성된 단백질과 망상구조를 하고 있는 모양이 관찰되 었다. 한편 일반 분쇄한 쌀 분말 종류별 $30 \%$ 를 첨가한 멥쌀 분말의 경우 크럼의 조직내부는 팽윤된 전분과 변성된 단백 질이 상호 작용하여 망상구조를 하고 있으며, 는 모양이 대조구보다 매끄럽게 관찰되었고, 고아미는 1,000 배율에서 는 구형과 타원형의 크고 작은 전분입자 표면의 매끄러움과 가운데 갈라진 부분과 전분이 손상되어 구형과 타원형보다 는 길쭉한 형태로 나타났다. 찐 찹쌀은 찐 멥쌀 분말보다 1,000 배율에서 더 많이 팽윤된 구형과 타원형의 전분입자 가 증가하고 윤곽이 뚜렷하였다. 따라서 쌀 종류별 분말을 첨가한 식빵의 품질은 찐 찹쌀, 찐 멥쌀, 고아미, 멥쌀 및 캄보디아 쌀 분말 순으로 유지되므로, 식빵의 상미기한을 3 일 정도로 하는 것이 적합한 것으로 판단된다. 


\section{감사의 글}

본 연구는 사)한국지속농업연구소 연구사업의 지원에 의해 이루어진 것이며 이에 감사드립니다.

\section{References}

1. Kum JS, Lee SH, Lee HY, Kim KH, Kim YI (1993) Effect of different milling methods on distribution of particle size of rice flours. Korean J Food Sci Technol, $25,541-545$

2. Gallagher E, Gormley TR, Arendt EK (2004) Recent advances in the formulation of gluten-free cereal-based products. Tkends Food Sci Technol, 15, 143-152

3. Suzuki A, Kagawa D, Fuji A, Ochiai R, Tokimitsu I Saito I (2002) Short- and long-term effects of ferulic acid on blood pressure in spontaneously hypertensive rats. Am J Hypertens, 15, 351-357

4. Bean MM (1986) Rice flour-its functional variations. Cereal Foods World, 31, 477-481

5. Joung YM (1998) Effect of damaged starch on rheological properties of dough ang bread baking properties. MS Thesis, Korea University, Korea, p 15-27

6. Park YK, Seog HM, Nam YJ, Shin DH (1988) Physicochemical properties of various milled rice flour. Korean J Food Sci Technol, 20, 504-510

7. Kim SS, Kang KA, Choi SY, Lee YT (2005) Effect of elevated steeping temperature on properties of wet-milled rice flour. J Korean Soc Food Sci Nutr, 34, 414-419

8. Ju JE, Nam YH, Lee KA (2006) Quality characteristics of sponge cakes with wheat-rice composite flour. Korean J Food Cookery Sci, 22, 923-929
9. Sanchez HD, Osella CA, De La Torre MA (2002) Optimization of gluten-free bread prepared from corn starch, rice flour, and cassava starch. J Food Sci, 67, 416-419

10. AACC (1990) Approved Methods of the American Association of Cereal Chemists. $8^{\text {th }}$ ed, American Association of Cereal Chemists Inc, MN, USA, p 10-10b, p 54-21, p 54-30

11. AACC (1991) Approved Method of the AACC. Method 02-52b. American Association of Cereal Chemists St Paul, MN, USA

12. Fessas D, Schiraldi A (1998) Texture and staling of wheat bread crumb: effects of water extractable proteins and 'pentosans'. Thermochim Acta, 323, 17-26

13. Puhr DP, D'appolonia BL (1992) Effect of baking absorption on bread yield, crumb moisture, and crumb water activity. Cereal Chem, 69, 582-586

14. Chabot JF, Hood LF, Liboff M (1979) Effect of scanning electron microscopy preparation methods on the ultrastructure of white bread. Cereal Chem, 56, 462-464

15. SAS (2004) SAA/STAT 9.1 User's guide. Statistical Analysis Systems Institute, Cary, NC, USA, p 421-480

16. Nakae K (1983) Baking Chemistry. Pan news Co Ltd., Tokyo, Japan, p 5-138

17. Park MK, Lee KS, Lee KH (2008) Effects of rice powder particle size in baked rice breads. J East Asian Soc Dietary Life, 18, 397-404

18. Kim JN, Shin WS (2009) Physical and sensory properties of chiffon cake made with rice flour. Korean J Food Sci Technol, 41, 69-76

19. Czuchajowska Z, Pomeranz Y, Jeffers HC (1989) Water activity and moisture content of dough and bread. Cereal Chem, 66, 128-132 